\title{
COMPARISON OF BLOOD PARAMETERS AND SOME MOTOR PERFORMANCE VALUES IN A FACULTY OF SPORT SCIENCES STUDENTS
}

Feyzullah Koca

Erciyes University, Sports Science Faculty, Turkey

\begin{abstract}
:
In this study is proposing to compare lipid and lipoprotein values in faculty of sport sciences students in order to investigate cardiovascular disease risks. The research included sports-educated college students. They were 20 wrestlers, 25 judo athletes and 30 soccer players. Comparison of age and height were used in the research and, to identify the differences among groups, one-way Anova and Scheffe tests were performed. In this study, vertical jumping value was not found statistically significant among the groups ( $p>0.05)$. In this study, aerobic and anaerobic power of the educated wrestlers and judo athletes were found to be different than the soccer players $(p<0.05)$. In our study, wrestlers and judo athletes' values are clearly higher than the values soccer players group in terms of total cholesterol (TC), triglyceride (TG), low density lipoprotein (LDL-C) amounts $(\mathrm{p}<0.01)$. In our study, wrestlers and judo athletes' values are found to be significantly lower than the values soccer players in terms of high-density lipoprotein (HDL-C) amounts $(\mathrm{p}<0.01)$. The ratio TC / HDL-C and LDL-C / HDL-C of educated judo athletes and wrestlers is higher than soccer players $(p<0.05)$. Conclusion: Faculty of sport sciences students who wrestlers, judo athletes and soccer players were found to be different in blood fat values. This difference in bloods fat are thought to be due to their training. Healthy risk factors for cardiovascular diseases of all three branch athletes were found to be low. Wrestler and Judo players were recommended to include more aerobic activities in their trainings.
\end{abstract}

Keywords: lipid, lipoprotein, wrestlers, judo athletes, soccer players

\section{Introduction}

Soccer is a team sport in which behaviors aiming at scoring and goal blocking a goal are displayed as a result of running with different tempo and movements that can be controlled with a ball that can be predicted where to go (Kılıç \& Toşur, 2018). Atan et al. 
(2012) in a study, the total physical activity levels of teachers and health professionals were not different and insufficient. Soccer is a fitful sport in which players need to perform many technical, physical, and tactical actions and previous research suggests that agility, reaction capacity, power development, repeated sprint ability and endurance capability shows determinant issues for success in soccer and other sports (Chtara et al., 2017; Y1lmaz et al., 2019; Özaslan et al., 2017). Soccer is defined as a multiple-sprint sport, reflecting the need for players to continuous running during a match (Abrantes et al., 2004). According to the duration of the competition and due to its vigorous physical activity, the wrestling is primarily an anaerobic sport that wrestlers utilize just about ninety percent of energy needed from the ATP-CP and lactic-acid energy systems (Dawes \& Roozen, 2012, Aksoy et al., 2020a). Wrestling and Judo are complicated sports branches that involve integrated actions and activities (Bostanci et al., 2017; Ermiş et al., 2019). Aerobic and anaerobic systems are needed together in wrestling and Judo (Ermiş et al., 2019, Aksoy et al., 2020b). The aerobic system in the athletes who use the speed and the maximum power in the anaerobic system in the competition or match supports the recovery in the fields where the effort is decreased in order to ensure the continuation of the struggle (Franchini et al., 2009). Atan et. al (2015) in study, it was found that the best performance which includes activities of aerobic endurance has been shown in the afternoon hours. Atan and Alaçam (2015) in study, was found that the effect of aerobic and anaerobic exercise on hematologic blood parameters was similar except for several parameters. In addition, previous study showed that the circulation parameters had been affected by aerobic and anaerobic exercises positively (Tahhan et al., 2018a; Tahhan et al., 2018b).

Both anaerobic and aerobic training can decrease total cholesterol, increase highdensity lipoprotein cholesterol values, and lower the total cholesterol/high-density lipoprotein cholesterol ratio. Among elite athletes, exercise continues to enhance favorable lipoprotein profiles (Çetin et al., 2019). Studies have shown that increasing risk factors in coronary heart diseases are high cholesterol, triglycerides, low-density lipoprotein cholesterol values and low high-density lipoprotein cholesterol values in blood parameters (Demirel et al., 2018). Positive effects of applied long regular exercises on physiological, physical, psychological and motoric features have been noticed and one of the most prominent positive effects of regular physical activate is on blood biochemistry (Pancar et al., 2018). Normal and well-tuned intensity aerobic exercise reduces blood lipid levels, total cholesterol, LDL cholesterol, triglycerides, while raises HDL cholesterol levels when estimated (Koç, 2011). Judo and wrestling have a very vigorous physical activity in sport branches. They also focused on that hypercholesterolemia and low levels of HDL-C were more uttered in power sports and anaerobic sports. A great number of studies show that the cholesterol is related with coronary heart disease (Çetinkaya and İmamoğlu, 2018; Güllü et al., 2013). Latest studies have shown that the dosed individually and programmed physical activity leads to raise the concentration of HDL cholesterol, and triglyceride, total and LDL cholesterol and other blood parameters (Labović et al., 2015; Pancar et al., 2018). However, investigators 
report contradictory findings related to the density and the training style that produce alterations in the lipid metabolism (Menevşe et al., 2014). LDL-/HDL-C ratio can show raised rate of arteriosclerosis disease. Low blood levels of HDL-C are a detached risk factor for cardiovascular disease (Boden 2000; Franceschini, 2001). Many parameters such as strength, speed, balance, flexibility, reaction time and endurance and mental ability are required to succeed in wrestling competitions (Pancar et al., 2016; Ermiş et al., 2019). Wrestling and judo are similar sport branches. Many factors influence the success of athletes, except motor performance capacities such as aerobic and anaerobic capacity. Again, many different parameters affect the success of soccer players. Blood fat values can also have an impact on success (Keskin et al., 2019).

In this study, it is aimed lipid and lipoprotein values of in faculty of sport sciences students to investigate cardiovascular disease risks. It is thought that there is a similar between lipid and lipoprotein values of wrestlers and judo athletes. Lipid and lipoprotein values of soccer players are thought to be different from wrestlers and judo athletes. Soccer players do aerobic training in their regular training more than wrestlers and judo athletes. This study is important in terms of comparing lipid and lipoprotein values of wrestlers, judo athletes, and soccer players. In addition, cardiovascular risk status of athletes was also studied.

\section{Material and Method}

\subsection{Subjects}

In this study, 20 wrestlers, 25 judo athletes and 30 soccer players were included. Participants are students who are studying in faculty of sport sciences.

\subsection{Measurements and Tests}

Anthropometric and motor performance measurements related to body compositions have been done in Sports facilities.

a. Measurement of Height and Body Weight: Body weights have been measured in kilograms via electronic scales (premier) with a t-shirt, a tight and bare feet. Heights have been measured in centimeters in the upright position with bare feet via Rodi Super Quality (Aslan and Ziyagil, 2020).

b. $\mathrm{MaxVO}_{2}$ : With a 12-minute running test; $\mathrm{MaxVO}_{2}(\mathrm{ml} / \mathrm{kg} / \mathrm{min})=$ Distance travelled $/ 12$ $(\mathrm{m} / \mathrm{min}) \times(0.2+3.5)=\mathrm{ml} / \mathrm{kg} / \mathrm{min}$.

c. Anaerobic Power (P): Bounce measure have been made via jump meter that has a measurement range between $5 \mathrm{~cm}-99 \mathrm{~cm}$, that is affixed in the waist and that shows digitally the bounced distance .

Anaerobic Power $(\mathrm{P})=\sqrt{ } 4.9 \times$ Body Weight $\times \sqrt{ } \mathrm{D}=\mathrm{kgm} / \mathrm{sec}$

$\mathrm{D}=$ vertically jumped distance $(\mathrm{m}$.

d. BMI (Body Mass Index) = BW (Body Weight) $\mathrm{kg} / \mathrm{BH}$ (Body Height) $\mathrm{m}^{2}=\left(\mathrm{kg} / \mathrm{m}^{2}\right)$

e. Measurement of the Blood Biochemical: Blood samples have been taken (12 hours later) in the mornings on an empty stomach without changing three week the diet of the 
men. The results of counting have been analyzed by using $5 \mathrm{ml}$ blood samples taken from forearm antecubital region in Hitachi 717 auto analyzer. The data obtained from the measurements have been recorded immediately after every measurement.

\subsection{Statistical Analysis}

Analyses were made on SPSS 23.00 version. Kolmogorov-Smirnov test was used in order to assess the normality of parameters. Comparison of age and height were used in this study and, to determine the differences between groups one-way Anova and Scheffe tests were performed. Statistical significances were accepted at $p<0.05$.

\section{Results}

Table 1: Comparison of anthropometric properties of subject

\begin{tabular}{|c|c|c|c|c|c|}
\hline Variables & Group & $\mathbf{n}$ & Mean & Standard deviation & F / Scheffe \\
\hline \multirow{3}{*}{$\begin{array}{l}\text { Age } \\
\text { (year) }\end{array}$} & Wrestling (1) & 20 & 22.44 & 0.29 & \multirow{3}{*}{1.66} \\
\hline & Judo (2) & 25 & 23.38 & 0.32 & \\
\hline & Soccer (3) & 30 & 22.79 & 0.23 & \\
\hline \multirow{3}{*}{$\begin{array}{l}\text { Height } \\
(\mathrm{cm})\end{array}$} & Wrestling (1) & 20 & 173.32 & 1.50 & \multirow{3}{*}{0.60} \\
\hline & Judo (2) & 25 & 173.94 & 1.31 & \\
\hline & Soccer (3) & 30 & 172.99 & 0.73 & \\
\hline \multirow{3}{*}{$\begin{array}{l}\text { Body Weight } \\
(\mathrm{kg})\end{array}$} & Wrestling (1) & 20 & 76.50 & 2.31 & \multirow{3}{*}{$\begin{array}{l}4.12^{*} \\
1,2>3\end{array}$} \\
\hline & Judo (2) & 25 & 76.46 & 1.93 & \\
\hline & Soccer (3) & 30 & 73.81 & 1.34 & \\
\hline \multirow{3}{*}{$\begin{array}{l}\text { BMI } \\
\left(\mathrm{Kg} / \mathrm{m}^{2}\right)\end{array}$} & Wrestling (1) & 20 & 25.47 & 0.60 & \multirow{3}{*}{$\begin{array}{l}3,18^{*} \\
1,2>3\end{array}$} \\
\hline & Judo (2) & 25 & 25.25 & 0.93 & \\
\hline & Soccer (3) & 30 & 24.55 & 0.97 & \\
\hline
\end{tabular}

$\mathrm{p}<0.05^{*}$

The age of the wrestlers has been detected as 22.44 years, Judo athletes 23.38 years, and soccer players 22.79 years, their height has been detected as wrestlers $173.3 \mathrm{~cm}$, Judo athletes $173.94 \mathrm{~cm}$, and soccer players $171.99 \mathrm{~cm}$. It was found BMI values $25.47 \mathrm{~kg} / \mathrm{m}^{2}$ for wrestlers, $25.25 \mathrm{~kg} / \mathrm{m}^{2}$ for judo athletes, and $24.55 \mathrm{~kg} / \mathrm{m}^{2}$ for soccer players.

Table 2: Comparison of aerobic and anaerobic power of subject

\begin{tabular}{|c|c|c|c|c|c|}
\hline Variables & Groups & $\mathbf{n}$ & Mean & Standard deviation & F / Scheffe \\
\hline \multirow{3}{*}{$\begin{array}{l}\text { Vertical jump } \\
(\mathrm{cm})\end{array}$} & Wrestling (1) & 20 & 62.10 & 5.61 & \multirow{3}{*}{1.24} \\
\hline & Judo (2) & 25 & 62.00 & 5.92 & \\
\hline & Soccer (3) & 30 & 61.00 & 9.64 & \\
\hline \multirow{3}{*}{$\begin{array}{l}\text { Aerobic power }\left(\mathrm{Max} \mathrm{VO}_{2}\right) \\
\mathrm{ml} / \mathrm{kg} / \mathrm{min}\end{array}$} & Wrestling (1) & 20 & 53.63 & 3.09 & \multirow{3}{*}{$\begin{array}{l}5.06^{*} \\
3>1,2\end{array}$} \\
\hline & Judo (2) & 25 & 53.72 & 3.17 & \\
\hline & Soccer (3) & 30 & 55.83 & 4.42 & \\
\hline \multirow{3}{*}{$\begin{array}{l}\text { Anaerobic power } \\
(\mathrm{kg}-\mathrm{m} / \mathrm{sec})\end{array}$} & Wrestling (1) & 20 & 133.92 & 3.71 & \multirow{3}{*}{$\begin{array}{l}6.89^{*} \\
1,2>3\end{array}$} \\
\hline & Judo (2) & 25 & 133.85 & 4.53 & \\
\hline & Soccer (3) & 30 & 127.58 & 6.42 & \\
\hline
\end{tabular}

$\mathrm{p}<0.05^{*}$ 
Vertical jump has been found $62.10 \mathrm{~cm}$ for wrestlers, $62.00 \mathrm{~cm}$ for judo athletes, and 61.00 $\mathrm{cm}$ for soccer players. Wrestlers' $\mathrm{Max} \mathrm{VO}_{2}$ and anaerobic power has been found 53.63 $\mathrm{ml} / \mathrm{kg} / \mathrm{min}$ and $133.92 \mathrm{~kg}-\mathrm{m} / \mathrm{sec}$ respectively. Judo athletes' $\mathrm{Max} \mathrm{VO}_{2}$ and anaerobic power has been found $53.72 \mathrm{ml} / \mathrm{kg} / \mathrm{min}$ and $133.85 \mathrm{~kg}-\mathrm{m} / \mathrm{sec}$ respectively. Soccer players Max $\mathrm{VO}_{2}$ and anaerobic power has been found $55.83 \mathrm{ml} / \mathrm{kg} / \mathrm{min}$ and $127.58 \mathrm{~kg}-\mathrm{m} / \mathrm{sec}$ respectively.

Table 3: Comparison of serum lipid levels of subject

\begin{tabular}{|c|c|c|c|c|}
\hline Variables & Groups & Mean & Standard deviation & F / Scheffe \\
\hline \multirow{3}{*}{$\begin{array}{l}\text { Total cholesterol } \\
(\mathrm{mg} / \mathrm{dl})\end{array}$} & Wrestling (1) & 187.31 & 2.82 & \multirow{3}{*}{$\begin{array}{c}12.58^{* *} \\
1,2>3\end{array}$} \\
\hline & Judo (2) & 185.56 & 3.68 & \\
\hline & Soccer (3) & 158.52 & 3.15 & \\
\hline \multirow{3}{*}{$\begin{array}{l}\text { Triglyceride } \\
\text { (mg/dl) }\end{array}$} & Wrestling (1) & 132.64 & 4.35 & \multirow{3}{*}{$\begin{array}{c}39.46^{* *} \\
1,2>3\end{array}$} \\
\hline & Judo (2) & 130.14 & 4.41 & \\
\hline & Soccer (3) & 84.84 & 2.12 & \\
\hline \multirow{3}{*}{$\begin{array}{l}\text { LDL-C } \\
\text { (mg/dl) }\end{array}$} & Wrestling (1) & 120.55 & 2.15 & \multirow{3}{*}{$\begin{array}{c}31.23^{* *} \\
1,2>3\end{array}$} \\
\hline & Judo (2) & 119.95 & 5.67 & \\
\hline & Soccer (3) & 101.62 & 5.54 & \\
\hline \multirow{3}{*}{$\begin{array}{l}\text { HDL-C } \\
(\mathrm{mg} / \mathrm{dl})\end{array}$} & Wrestling (1) & 49.76 & 1.62 & \multirow{3}{*}{$\begin{array}{l}3.15^{*} \\
1,2<3\end{array}$} \\
\hline & Judo (2) & 49.24 & 1.28 & \\
\hline & Soccer (3) & 56.64 & 1.76 & \\
\hline
\end{tabular}

$\mathrm{p}<0.05^{*} \mathrm{p}<0.01^{* *}$

In this study, it found Total cholesterol values on wrestlers $187.31 \mathrm{mg} / \mathrm{dl}$, judo athletes $185.56 \mathrm{mg} / \mathrm{dl}$, and soccer players $158.52 \mathrm{mg} / \mathrm{dl}$. In this study, it found triglyceride values on wrestlers $132.64 \mathrm{mg} / \mathrm{dl}$, judo athletes $130.14 \mathrm{mg} / \mathrm{dl}$, and soccer players $84.84 \mathrm{mg} / \mathrm{dl}$. In this study, it found LDL-C values on wrestlers $120.55 \mathrm{mg} / \mathrm{dl}$, judo athletes $119.95 \mathrm{mg} / \mathrm{dl}$, and soccer players $101.62 \mathrm{mg} / \mathrm{dl}$. In this study, it found HDL-C values on wrestlers 49.76 $\mathrm{mg} / \mathrm{dl}$, judo athletes $49.24 \mathrm{mg} / \mathrm{dl}$, and soccer players $56.64 \mathrm{mg} / \mathrm{dl}$.

Table 4: Cardiovascular risk factors of subject

\begin{tabular}{llccc}
\hline Mg/dl & Groups & Mean & Standard deviation & F/Sheffe \\
\hline \multirow{3}{*}{ TC/HDL-C } & Wrestlers & 3.77 & 0.12 & \multirow{2}{*}{$5.12^{*}$} \\
\cline { 2 - 4 } & Judo athletes & 3.76 & 0.13 & $1,2>3$ \\
\cline { 2 - 4 } & Soccer players & 2.80 & 0.11 & $4.16^{*}$ \\
\multirow{3}{*}{ LDL-C/HDL-C } & Wrestlers & 2.44 & 0.14 & $1,2>3$ \\
\cline { 2 - 4 } & Judo athletes & 2.42 & 0.13 & \\
\cline { 2 - 4 } & Soccer players & 1.79 & 0.10 & \\
\hline
\end{tabular}

TC/HDL-C ratios found to be $3.76 \mathrm{mg} / \mathrm{dl}$ for judo athletes, $3.77 \mathrm{mg} / \mathrm{dl}$ for wrestlers, and $2.80 \mathrm{mg} / \mathrm{dl}$ for soccer players. LDL-C/HDL-C ratios found to be $2.42 \mathrm{mg} / \mathrm{dl}$ for judo athletes, $2.44 \mathrm{mg} / \mathrm{dl}$ for wrestlers, and $1.79 \mathrm{mg} / \mathrm{dl}$ for soccer players. 


\section{Discussion and Conclusion}

In this study, we have not found significant differences between age and height of the three groups ( $p>0.05)$. Body weight and body mass index values of the soccer players were significantly lower than judo and wrestlers $(p<0.05)$. In this study, wrestlers and judo athletes were weight than soccer players. This suggests that wrestlers and judo athletes have more muscular structure than soccer players. In classification for BMI: BMI categories were normal weight $\left(22-23.9 \mathrm{~kg} / \mathrm{m}^{2}\right.$, the referent) and overweight (24-26.9 $\mathrm{kg} / \mathrm{m}^{2}$ ), (Hsu et al., 2018). In general, if the body mass index is up to $25 \mathrm{~kg} / \mathrm{m}^{2}$, everybody is considered as healthy and after $25 \mathrm{~kg} / \mathrm{m} 2$ as sick (Turgut et al., 2018). But this classification is for sedentary people. In a study of Turkish footballers, the average body mass index of professional footballers was found to be $23.46 \mathrm{~kg} / \mathrm{m}^{2}$ and $22.87 \mathrm{~kg} / \mathrm{m}^{2}$ for amateurs (Kılıç and Toşur, 2018). Wittich et al. (1999) reported that the average BMI of 24 professional footballers in their study was $24.5 \mathrm{~kg} / \mathrm{m}^{2}$. Bayraktar and Kocak (2017) in a study, İt found Olympic level Greco-Roman and Freestyle wrestlers BMI $27.7 \mathrm{~kg} / \mathrm{m}^{2}$. In this study, Body Mass index values were found to be around $25 \mathrm{~kg} / \mathrm{m}^{2}$. Since they are athletes in all three groups, they should not be considered as risky in health category.

Lower body anaerobic power has been assessed through a vertical jump test with counter-movement. The national male freestyle team of United States in 1997 had an average of $60 \mathrm{~cm}$ (Utter et al., 2002). Unpublished data from the US Olympic Committee (Callan et al., 2000) showed that male wrestlers of Greco-Roman team had an average counter-movement vertical jumps of $62 \mathrm{~cm}$. Data provided by Podlivaev for Russian athletes ranged $56.70 \mathrm{~cm}$ to $66.10 \mathrm{~cm}$ (https://simplifaster.com/articles). In a study on Turkish footballers, the vertical jump value of professional soccer players was $59.08 \mathrm{~cm}$ and for amateur players was $55.25 \mathrm{~cm}$ (Kılıç and Toşur, 2018). İri et al. (2017) stated that the average vertical jump of elite soccer player was $51.40 \mathrm{~cm}$. Aslan and Koç (2015) found the average vertical jump of amateur soccer players to be $58.49 \mathrm{~cm}$. In this study, vertical jump value was found to be around $60 \mathrm{~cm}$ in all three groups. Vertical warming value was not found statistically significant among the groups ( $p>0.05)$.

Trainers were providing athletes with $\mathrm{VO}_{2}$ max's $60-70+\mathrm{ml} / \mathrm{kg} / \mathrm{min}$ (Sharratt, 1984). Reilly et al. (2000) assert that $\mathrm{VO}_{2} \mathrm{max}$ is not a unique factor of performance capability in soccer and claims that VO2max $>60 \mathrm{~mL} / \mathrm{kg} / \mathrm{min}$ provides the lowest limit to have the physiological skills for success in men's elite soccer. In contrast, Stølen et al (2005) claim that it may be acceptable to expect about $70 \mathrm{ml} / \mathrm{kg} / \mathrm{min}$ for a $75-\mathrm{kg}$ professional soccer player, a value similar to that in elite middle-distance athletes. Tonnessen et al. (2013) in a study, it found national team $50.2 \mathrm{ml} / \mathrm{kg} / \mathrm{min}$, 1 st division $49.0 \mathrm{ml} / \mathrm{kg} / \mathrm{min}$, and 2nd division $48.2 \mathrm{ml} / \mathrm{kg} / \mathrm{min}$ on soccer for Norwegian. Ergün et al. (2005) in a study, it found $\mathrm{VO}_{2}$ max values is $50.6 \mathrm{ml} / \mathrm{kg} / \mathrm{min}-63.7 \mathrm{ml} / \mathrm{kg} / \mathrm{min}$ for soccer. The maximum oxygen intake for elite soccer players has been found in many researches and it ranges between $56-70 \mathrm{ml} / \mathrm{kg} / \mathrm{min}$, which is partly associated with the standard of play and different positions (Ergun et al., 2005). In a study on Turkish soccer players, it found Aerobic Capacity (MaxVO2) of professional players $52.47 \mathrm{ml} / \mathrm{kg} / \mathrm{min}$ and 53.94 
$\mathrm{ml} / \mathrm{kg} / \mathrm{min}$ for amateurs (K1lıç \& Toşur, 2018). Iri et al. (2017) reported that aerobic capacity of elite footballers was $52.65 \mathrm{ml} / \mathrm{kg} / \mathrm{min}$. Aslan and Koç (2015) stated the average $\mathrm{MaxVO}_{2}$ of amateur football players as $50.01 \mathrm{ml} / \mathrm{kg} / \mathrm{min}$. Zi-Hong et al. (2013) in a study, the major results were VO2max: $50.58 \mathrm{ml} / \mathrm{kg} / \mathrm{min}$. In general, elite male wrestlers shows the highest $\mathrm{VO}_{2}$ values of between 50.4 and $62.4 \mathrm{ml} / \mathrm{kg} / \mathrm{min}$ (Horswill, 1992). Yoon (2002) found that national and international wrestlers who took part in international competitions had the maximal oxygen uptake between 53 and 56 ( $\mathrm{ml} / \mathrm{kg} / \mathrm{min})$. An article published by Huber-Wozniak (2009) found an average $\mathrm{VO}_{2}$ in male elite wrestlers was $59.8 \mathrm{ml} / \mathrm{kg} / \mathrm{min}$, and females were $49.7 \mathrm{ml} / \mathrm{kg} / \mathrm{min}$. İmamoğlu et al. (1999a) in a study, it found judo athlete's average relative Max VO2 $44.37 \mathrm{ml} / \mathrm{kg} /$ min. The value of $\mathrm{MaxVO}_{2}$ in the study of Imamoğlu et al. (2001) was $50.29 \mathrm{ml} / \mathrm{kg} / \mathrm{min}$; the MaxVO2 value in the study of Ağaoğlu et al. (2001) was $51.28 \mathrm{ml} / \mathrm{kg} / \mathrm{min}$. In a study of Max VO2 and anaerobic power of the wrestlers have been found $52.4 \mathrm{ml} / \mathrm{kg} / \mathrm{min}$ and $127.89 \mathrm{~kg}-\mathrm{m} / \mathrm{sec}$ respectively İmamoğlu et al. (2005). Maximal oxygen uptake of the wrestlers in international competitions is around 53 and $56 \mathrm{ml} / \mathrm{kg} / \mathrm{min}$ (İmamoğlu et al., 2005). In a research on Turkish soccer players, anaerobic power value of professional soccer players was determined to be $128.90 \mathrm{~kg}-\mathrm{m} / \mathrm{sec}$ and anaerobic power value of amateur soccer players was determined as $117.21 \mathrm{~kg}-\mathrm{m} / \mathrm{sec}$ (Kılıç and Toşur, 2018). Iri et al. (2017) reported the average anaerobic power of elite soccer players $127.60 \mathrm{~kg}-\mathrm{m} / \mathrm{sec}$. Aslan and Koç (2015) found that the average anaerobic power of amateur soccer players was $119.07 \mathrm{~kg}-\mathrm{m} / \mathrm{sec}$.

In another study, Aslan et al. (2010) stated that the average anaerobic power of professional soccer players was $131.52 \mathrm{~kg}-\mathrm{m} / \mathrm{sec}$. Anaerobic performances of a freestyle wrestler are more similar to power athletes such as sprinters, throwers, weightlifters than endurance athletes. Similarly, the anaerobic power of the upper and lower body of male wrestlers is much greater than the corresponding values in non-athletic men of similar age (Horswill, 1992). By İmamoğlu et al. (2001) in a study, anaerobic power was found to be $132.00 \mathrm{~kg}-\mathrm{m} / \mathrm{sec}$ for judo athletes. By Ağaoğlu et al. (2001) in a study, anaerobic power was found to be $130.09 \mathrm{~kg}-\mathrm{m} / \mathrm{sec}$ for judo athletes. Anaerobic power of University wrestlers has been found $115.67 \mathrm{~kg}-\mathrm{m} / \mathrm{s}$ (Akkuş ve İnal, 1999). Crawford (1996) stated that there is a correlation between weight and anaerobic power, and that there is an increase in anaerobic power with the increase in weight. Caglar et al. (1997) stated that anaerobic power increases as body weight increases. Besides, in the study of Imamoglu et al. (1999), it was found that the increase in weight shows parallelism with the increase in anaerobic power. İmamoğlu et al. (1999b) in a study, it found anaerobic power to increase, as the weight increases. In this study, aerobic power of soccer players found high than wrestlers and judo athletes. Anaerobic power of soccer players is lower than wrestlers and judo athletes. In this study, aerobic and anaerobic power of the wrestler and judo athletes were found to be different than the soccer players $(p<0.05)$. This is due to the fact that the bodyweight of the wrestlers and judo player is higher than the soccer players and the 12minute running distances are lower. It is recommended that wrestlers and judo athletes give more space to aerobic activities throughout trainings. 
Total cholesterol and triglyceride laboratory reference interval are $0-200 \mathrm{mg} / \mathrm{dl}$ (Menevşe et al., 2013). Total cholesterol and triglyceride values is to be higher with sedentary people according athletes (Koç, 2011). In other a study, found that athletes' serum Total cholesterol and levels are significantly lower than the levels of sedentary people (Turgut et al., 1998). In our study, wrestlers and judo athletes' values are found to be significantly higher than the values soccer players group in terms of total cholesterol and triglyceride amounts $(\mathrm{p}<0.01)$.

Laboratory reference interval is $0-160 \mathrm{mg} / \mathrm{dl}$ for LDL-C (Menevşe et al., 2014). In a study, between athletes and sedentary there found no significant difference in terms of LDL levels (Turgut et al., 1998). In our study, wrestlers and judo athletes' values are found to be significantly higher than the values soccer players group in terms of LDL-C amounts $(\mathrm{p}<0.01)$.

Laboratory reference interval is $25-75 \mathrm{mg} / \mathrm{dl}$ for HDL-C, and $0-160 \mathrm{mg} / \mathrm{dl}$ for LDLC (Menevşe et al., 2014). LDL-C level is with sedentary people and HDL-C level is high with athletes (Koç, 2011). In a study on wrestlers and sedentary people, showed that HDL-C level is significantly higher with wrestlers, but LDL-C level is lower (Yamaner et al., 2010). In our study, wrestlers and judo athletes' values are found to be significantly lower than the values soccer players in terms of HDL-C amounts $(p<0.01)$.

LDL -C/HDL $C$ ratio and LDL C/HDL $C$ ratio can show arteriosclerosis disease risk (Akyol and İmamoğlu, 2019). The risk factor is elevated if the cardiovascular risk ratios (TC/HDL-C) is advanced than 5; the risk factor is falling if the ratio is under than 3.5 (Lemieux et al., 2001). In this study, ratio TC / HDL-C and in LDL-C / HDL-C ratio for judo athletes, wrestlers, and soccer players were not risk factor. Also, in this study, is meaningful that the ratio TC / HDL-C and LDL-C / HDL-C of judo athletes and wrestlers is higher than soccer players $(\mathrm{p}<0.05)$. Wrestling and Judo are classified as a poweranaerobic based sport on the basis of its character of training, match times. Wrestlers and Judo athletes may be advised to include more aerobic activities in training.

In conclusion, faculty of sport sciences students who wrestlers, judo athletes and soccer players were found to be different in blood fat values (TC, TG, LDL-C, and HDLC). Wrestlers and judo athletes have higher levels of harmful blood fat more than soccer players. HDK-K values, which are considered as beneficial cholesterol, are higher in footballers than in wrestlers and judo athletes. This difference in bloods fat are thought to be due to their training. Healthy risk factors for cardiovascular diseases of all three branch athletes were found to be low. Wrestler and Judo players were recommended to include more aerobic activities in their training. It is thought that blood fat values are normal due to the participants' sports education and trainings. 


\section{References}

Abrantes, C., Maçãs, V., \& Sampaio, J. (2004). Variation in football players' sprint test performance across different ages and levels of competition. Journal of Sports Science $\mathcal{E}$ Medicine, 3(1), 44

Ağaoğlu S. A., İmamoğlu O., Kishalı N. F., Çebi M. (2001). An Analysis of Specific Physiological and Anthropometric Characteristics of Turkish Men's National Judo Team Athletes, Atatürk University Journal of Physical Education and Sport Sciences, 1 (2-4),59-66

Akkuş, H., İnal, A. N. (1999). Measurement and comparison of back, paw, leg strength and anaerobic strength of sportsmen students in Selçuk University Men's basketball, wrestling and volleyball teams, Journal of Physical Education and Sport Sciences, 1, 82-87

Aksoy, Y. \& Aslan, H. \& İmamoğlu, O. (2020a). Comparison of Attention Levels According to Sport Status and Age Category in Students Turkish Studies, 15(3), 1473-1483.

Aksoy, Y., Aslan, H., İmamoğlu, O. (2020b). Performance Development of Wrestlers in Sport Education Centre, Turkish Journal of Sport and Exercise, Volume: 22 - Issue: 1 - Pages: 104-110.

Aslan C. S., İnan T. ve Akalan C. (2010). Comparison of some physical and physiological characteristics of a professional football team and physical education and sports school students. E-Journal of New World Sciences Academy Sports Sciences, 5 (1), 4758.

Aslan H. Ziyagil M. A. (2020). Relationships between body mass index and skinfold thickness of exercised and sedentary young adults, African Educational Research Journal,8(3):422-431.

Aslan, C., S., ve Koç, H. (2015). Comparison of Physical, Physiological and Motoric Characteristics of Amateur Footballers. CBÜ Journal of Physical Education and Sport Sciences, 10(1), 56-65.

Atan T., Alaçam H. (2015). The effects of acute aerobic and anaerobic exercise on blood parameters. The Anthropologist, January 19(1), 87-93.

Atan T., Tural E., İmamoğlu O., Çiçek G., Tural Ş. (2012). Physical activity levels of teachers and health professionals in Turkey. Health MED, 6(6), 1935-1942.

Atan T., Unver S., Islamoglu I., Cavusoglu G. (2017). Endurance performance according to circadian cycle. Anthropologist. 27(1-3), 32-36.

Bayraktar I., Kocak H. (2017). A Study of Profile and Comparison for Turkish GrecoRoman and Freestyle Wrestlers who Prepared for Rio 2016, Science, Movement and Health, Vol. XVII, Issue 2:190-199.

Boden W. E. (2000). High-density lipoprotein cholesterol as an independent risk factor in cardiovascular disease: assessing the data from Framingham to the Veterans Affairs High-Density Lipoprotein Intervention Trial. Am J Cardiol, 86 (12A) 19L- 22. 
Bostanci, O., Özdal, M., Mayda, H., \& Kabadayi, M. (2017). The effect of preparation period trainings on respiratory muscle strength of hearing-impaired judokas. Archives of Budo Science of Martial Arts and Extreme Sports, 13, 97-102.

Bott, C. (2020). Concurrent Training: Implications for Freestyle Wrestling Performance Striving for Optimal Training Practice - SimpliFaster. Retrieved 26 October 2020, from https://simplifaster.com/articles/concurrent-training-freestyle-wrestlingperformance/.

Çağlar, H. A., Gokmen, A., Hazir, M. ve Kuscu, O. (1997). Relationship between aerobic and anaerobic power and hemoglobin, body fat ratio and vital capacity in male soccer players, Journal of Football Science and Technology, Vol. 4/4, 30-32.

Callan, S. D., D. M. Brunner, K. L. De-volve, S. E. Mulligan, J. Hesson, R. L. Wilber, and J. T. Kearney. (2000). Physiological profiles of elite freestyle wrestlers. J. Strength Cond. Res. 14(2), 162-169.

Çetin S., Ece C., Şen M., Çetin H. N., Aydoğan A. (2019). The Effects of Pilates and Aerobic Exercise on Blood Pressure, Heart Rates, and Blood Serum Lipids in Sedentary Females, Journal of Education and Training Studies, Vol. 7, No. 4,229-235.

Çetinkaya G., Imamoğlu G. (2018). Investigation of the Effect of Plates-Aerobic Exercises on Body Composition and Body Image in Obesity Female, The Journal of International Social Research, Volume: 11 Issue: 59,1451-1456.

Chtara, M., Rouissi, M., Haddad, M., Chtara, H., Chaalali, A., Owen, A., \& Chamari, K. (2017). Specific physical trainability in elite young soccer players: efficiency over 6 weeks' in-season training. Biology of Sport, 34(2), 137.

Crawford, S. M. (1996). Anthropometry. In measurement in pediatric exercise science. Docherty, D. (Ed.) Champaing, IL: Human Kinetics. (Almuzaini, S. K. (2007) Muscle function in Saudi children and adolescents: relationship to anthropometric characteristics during growth. Pediatric Exercise Science, Vol. 19, No: 319.

Dawes J., Roozen M. eds. (2012). Developing agility and quickness, Human Kinetics.

Demirel N., Özbay S., Kaya F. (2018). The Effects of Aerobic and Anaerobic Training Programs Applied to Elite Wrestlers on Body Mass Index (BMI) and Blood Lipids, Journal of Education and Training Studies, Vol. 6, No. 4, 58-62.

Ergün M., İşlegen Ç., Acar M. F., Özkol Z., Taşyürek Z. (2005). Anaerobic Capability of Soccer Players with Differing Aerobic Power Levels, Journal of Sports Medicine, Vol. 40, 35-42.

Ermiş E., Satıcı A., İmamoğlu O. (2019). 12th World University Wrestling Championship Women's Competitions Technical Analyses, Turkish Studies Social Sciences,4(3), 1169-1178.

Ermiş, E., Yılmaz, A. K., \& Mayda, M. H. (2019). Analysis of Respiratory Functions and Respiratory Muscle Strength of Martial Arts Athletes. International Journal of Applied Exercise Physiology, 8(1), 10-17.

Ermiş, E., Yilmaz, A. K., Mayda, H., \& Ermis, A. (2019). Analysis of respiratory function and muscle strength of elite judo athletes and sedentary females. 
Franceschini G. (2001). Epidemiologic evidence for high-density lipoprotein cholesterol as a risk factor for coronary artery disease. Am J Cardiol, 88 (12A) 9N-13N.

Güllü, E., Güllü, A., Cicek, G., Yamaner, F., İmamoğlu, O., \& Gumusdağ, H. (2013). The effects of aerobic exercises on cardiovascular risk factors of sedentary women. Int. J. Acad. Res, 5,160-167.

Horswill C. A. (1992). Applied physiology of amateur wrestling. Sports Medicine, 14(2), 114-143.

Hsu, C. C., Wahlqvist, M. L., Wu, I. C., Chang, Y. H., Chang, I. S., Tsai, Y. F., \& Hsiung, C. A. (2018). Cardio metabolic disorder reduces survival prospects more than suboptimal body mass index irrespective of age or gender: a longitudinal study of 377,929 adults in Taiwan, BMC Public Health, 18(1), 142.

Hubner-Wozniak, E. Kosmol, A., Gajewski, J. (2009).Aerobic fitness of elite female and male wrestlers. Biology of Sport. Vol 26(4), 339-348 .

İmamoğlu O., Ağaoğlu S. A., Kishali N. F., Çebi M. (2001). Relationship Between Aerobic, Anaerobic Power, Body Fat Rate, Hand Grip Strength, and Vital Capacity in Men's National Judacas, Atatürk University Journal of Physical Education and Sport Sciences, 1(2-4),96-100.

İmamoğlu O., Çebi M., Kishali N. F., İmamoğlu H. (1999a). Analysis of Body Composition Parameters in Turkish Judo Men's National Team, Atatürk University Journal of Physical Education and Sport Sciences, 1(1),12-18.

İmamoğlu O., Çebi M., Kishali N. F., Tunç T. (1999b). Analysis of Some Anthropometric and Physiological Parameters in Judo Women's National Team Athletes, Atatürk University Journal of Physical Education and Sport Sciences,1 (1),34-40.

İmamoğlu, O., Atan, T., Kishali, N. F., Burmaoglu, G., Akyol, P., Yıldırım, K. (2005). Comparison of lipid and lipoprotein values in men and women differing in training status. Biol of Sport; 22(3), 261-70.

İri R., Yılmaz A., Aktuğ Z. B. (2017). Comparison of physical fitness levels and motoric characteristics of elite football and handball players, Journal of Sport and Performance Research, 8, 19-25.

Keskin Ö. D. Y., İmamoğlu O., Kabadayı M. (2019). Effect of Handedness and Footedness on Some Motoric Characteristics in Amateur Soccer Players, Journal of Education and Training Studies, 7(12), 13-21.

Kılıç T., Toşur M. A. A. (2018). Comparison of Some Parameters of Football Players According to Their Status, The Journal of International Social Research, 11(61), 12831291.

Koc H. (2011). The Comparison of Blood Lipid Levels of Athletes and Sedentary College Students. Pak J Med Sci. 27(3), 622-25.

Labović S. B., Đonović N., Andrejević V., Banjari I, Kurgaš H., Zejnilović M. (2015). Lipid Status of Professional Athletes, MD-Medical Data, 7(1), 021-025.

Lemieux, I., Lamarche, B., Couillard, C., Pascot, A., Cantin, B., Bergeron, J., \& Després, J. P. (2001). Total cholesterol/HDL cholesterol ratio vs LDL cholesterol/HDL 
cholesterol ratio as indices of ischemic heart disease risk in men: the Quebec Cardiovascular Study. Archives of internal medicine, 161(22), 2685-2692.

Menevşe A., İmamoğlu O., Kabadayı M., Demirhan B. (2014). The comparison of some blood parameters of elite athletes and sedentary people, HealthMED - Volume 8 / Number 4, 523-528.

Menevse, A., İmamoğlu, O., Kabadayı M. (2013). A comparison of the national wrestling team's blood biochemical levels before and after the camp. International Journal of Academic Research Part A; 5(6), 66-71.

Özaslan, B. R., Biçer, M., Özdal, M., Vural, M., \& Şan, G. (2017). Investigation of visual and auditory simple reaction time of individuals with mental retardation. European Journal of Special Education Research. 2(3), 65-76.

Pancar, S., Tokgöz, O., \& Topçu, H. (2018). The effect of 8-week exercise program on some hematological parameters in obese children. European Journal of Physical Education and Sport Science.

Pancar, Z., Özdal, M., \& Vural, M. (2018). The Effect of a Four-Week Physical Activity Program on Liver Enzyme Levels, Uric Acid, Urea and Creatine Kinase Activity in Obese and Overweight Children. Scholars Journal of Arts, Humanities and Social Sciences, 6(7), 1485-1489.

Pancar, Z., Özdal, M., Pancar, S., \& Biçer, M. (2016). Investigation of Visual and Auditory Simple Reaction Time of 11-18 Aged Youth. European Journal of Physical Education and Sport Science, v1i4.

Reilly T., Bangsbo J., Franks A. (2000). Anthropometric and physiological predispositions for elite soccer. J Sports Sci. 18(9), 669-683.

Sharratt M. T., Taylor A. W., Song T. M. (1986). A physiological profile of elite Canadian freestyle wrestlers. Can J Appl Sport Sci 11:100-105

Stølen T., Chamari K., Castagna C., Wisløff U. (2005). Physiology of soccer: an update. Sports Med. 35(6), 501-536.

Tahhan, A. M. A. A., Özdal, M., Vural, M., \& Mayda, M. H. (2018b). Acute effects of aerobic and anaerobic exercises on circulation parameters. European Journal of Physical Education and Sport Science. 4(3), 72-79.

Tahhan, A. M. A. A., Özdal, M., Vural, M., \& Pancar, Z. (2018a). Influence of aerobic and anaerobic exercise on oxygen saturation. European Journal of Physical Education and Sport Science. 4(2), 188-196.

Tønnessen E., Hem E., Leirstein S., Haugen T., Seiler S. (2013). Maximal Aerobic Power Characteristics of Male Professional Soccer Players, 1989-2012, International Journal of Sports Physiology and Performance, 8, 323-329.

Turgut G., Genç O., Kaptanoğlu B. (1998). Determination of Differences of Blood Lipid Fractions between Athletes and Sedentary People, SDÜ Tıp Faculty Sci. 5(1), 33-37

Wittich A., Mautalen C. A., Oliveri M. B., Bagur A., Somoza F., Rotemberg E. (1999). Professional Football (Soccer) Players Have a Markedly Greater Skeletal Mineral Content Density and Size than Age- and BMI Matched Controls, Calcified Tissue. New York. 
Yamaner F., Bayraktaroğlu T., Atmaca H., Ziyagil M. A., Tamer K. (2010). Comparison of Serum Leptin ve Serum Lipoprotein Levels of Turkish International Wrestlers and Sedentary People, Türk J Med Sci.40 (3), 471-77.

Yılmaz, A. K., Kabadayı, M., Bostancı, Ö., Özdal, M., \& Mayda, M. H. (2019). Analysis of isokinetic knee strength in soccer players in terms of selected parameters. Physical education of students, 23(4), 209-216.

Yoon J. (2002). Physiological profiles of elite senior wrestlers. Sports Medicine. 32, 225-233

Zi-Hong H, Lian-Shi F, Hao-Jie Z, Kui-Yuan X, Feng-Tang C, Da-Lang T, Ming-Yi L, Lucia $\underline{\text { A }}$ Fleck SI. (2013). Physiological profile of elite Chinese female wrestlers, IStrength Cond Res. 27(9), 2374-95. 

be applied to their work. Under the terms of this license, no permission is required from the author(s) or publisher for members of the community to copy, distribute, transmit or adapt the article content, providing a proper, prominent and unambiguous attribution to the authors in a manner that makes clear that the materials are being reused under permission of a Creative Commons License. Views, opinions and conclusions expressed in this research article are views, opinions and conclusions of the author(s). Open Access Publishing Group and European Journal of Physical Education and Sport Science shall not be responsible or answerable for any loss, damage or liability caused in relation to/arising out of conflict of interests, copyright violations and inappropriate or inaccurate use of any kind content related or integrated on the research work. All the published works are meeting the Open Access Publishing requirements and can be freely accessed, shared, modified, distributed and used in educational, commercial and non-commercial purposes under a Creative Commons attribution 4.0 International License (CC BY 4.0). 